\title{
A Review: Human Erythrocyte Acetylcholinesterase
}

\author{
Fritz Herz ${ }^{[124]}$ and Eugene Kaplan \\ Departments of Pediatrics, Sinai Hospital, and the Johns Hopkins University School of Medicine, Baltimore, Maryland, USA
}

\begin{abstract}
Introduction
In recent years the erythrocyte membrane has received considerable attention by many investigators. Numerous reviews on the composition [21, 111], immunologic $[85,116]$ and rheologic [65] properties, permeability [73], active transport [99], and molecular organization $[109,113,117]$, attest to this interest. Although many studies relating to membrane enzymes have appeared, systematic reviews of this area are limited. More than a dozen enzymes have been recognized in the membrane of the human erythrocyte, although changes in activity associated with pathologic conditions are found regularly only with acetylcholinesterase (EC. 3.1.1.7). Although the physiologic functions of erythrocyte acetylcholinesterase remain obscure, the location of this enzyme at or near the cell surface gives it special significance in studies of cellular membranes and the activity alterations seen in several hemolytic disorders may be of importance in understanding certain basic disease processes. Present knowledge concerning exythrocyte acetylcholinesterase as related to health and disease, age of the individual, and erythrocyte aging is so diffuse that a review of this subject seems to be warranted.
\end{abstract}

\section{Cholinesterases}

Cholinesterases are enzymes, present almost exclusively in animal tissues, that catalyze the hydrolysis of acetylcholine into acetic acid and choline. Acetylcholine was discovered over 100 years ago, but it was not known until the 1920 's that this substance was widespread in animal tissues and that it was important for the functioning of nervous tissue. After acetylcholine was found in animal tissues, it was shown that the physiologic action of this ester was inhibited by extracts of heart tissue [66]. Later studies indicated that the inactivation of acetylcholine was caused by the action of an enzyme [28]. It then became apparent that this enzyme was an esterase, hence the term "choline esterase" was coined [100]. Further studies established that more than one type of cholinesterase occurs in the animal body, differing in substrate specificity and in other properties. Alles and Hawes [1] compared the cholinesterase of human erythrocytes with that of human serum and found that, although both enzymes hydrolyzed acetyl- $\alpha$-methylcholine, only the erythrocyte cholinesterase could hydrolyze acetyl- $\beta$-methylcholine and the two diastereomeric acetyl- $\alpha: \beta$-dimethylcholines. These differences have been used to delineate the two main types of cholinesterase: $(l)$ acetylcholinesterase, or true, specific, E-type cholinesterase (acetylcholine acetylhydrolase, EC. 3.1.1.7) and (2) cholinesterase or pseudo, nonspecific, s-type cholinesterase (acylcholine acylhydrolase, EC. 3.1.1.8).

Acetylcholinesterase is found in the nervous tissue of all animals and in the erythrocytes of most of them, whereas pseudocholinesterase is found in lesser amounts in the nervous tissue of all animals and in the serum of most of them [4]. The most important differences between acetylcholinesterase and pseudocholinesterase are indicated in Table I. Although other nonspecific esterases that also hydrolyze acetylcholine are present in many tissues, they can be distinguished from the cholinesterases by their insensitivity to inhibition by eserine.

\section{Some Properties of Acetylcholinesterase}

Acetylcholinesterase possesses two adjacent binding sites for the substrate. One site is "anionic," and it binds the cationic quaternary nitrogen of acetylcholine. The other site is "esteratic," formed by a serine residue and by another nucleophilic group (imidazole of a histidine residue) that accepts the proton released during the enzyme reaction. While the anionic site attracts the quaternary nitrogen of the substrate, the 
Table $I$. Characteristics of cholinesterases ${ }^{\mathbb{1}}$

\begin{tabular}{lcc}
\hline & $\begin{array}{c}\text { Acetylcho- } \\
\text { linesterase }\end{array}$ & $\begin{array}{c}\text { Pseudocho- } \\
\text { linesterase }\end{array}$ \\
\hline $\begin{array}{l}\text { Optimum pH } \\
\text { Inhibition by excess substrate }\end{array}$ & $\begin{array}{c}7.5-8.0 \\
+\end{array}$ & 8.5 \\
$\begin{array}{l}\text { Hydrolysis of } \\
\text { Tributyrine }\end{array}$ & - & - \\
$\quad \begin{array}{c}\text { Acetyl- } \beta \text {-methylcholine } \\
\text { Benzoylcholine }\end{array}$ & + & - \\
$\begin{array}{l}\text { Hydrolysis rate with butyrylcholine } \\
\quad \text { (relative to acetylcholine) }\end{array}$ & $10 \%$ & $200 \%$ \\
$\begin{array}{l}\text { Inhibition by } \\
\text { Eserine }\end{array}$ & ++++ & ++++ \\
Quinidine & + & ++++ \\
Diisopropylphosphofluoridate & ++ & ++++ \\
\hline
\end{tabular}

1 After the data of Augustinsson [4]. Acetylcholinesterase: erythrocytes, nervous tissue, brain, placenta. Pseudocholinesterase: serum, pancreas, glands.

electrophilic carbon of the carbonyl group at the esteratic site forms a covalent bond with the oxygen of serine. The alcoholic portion is split off from the acetylcholinesterase-substrate complex, and the acetylated esteratic site reacts with water to form acetic acid and the intact enzyme. Substances that bind at the anionic site (simple quaternary compounds) are reversible acetylcholinesterase inhibitors, since they prevent attachment of the substrate. Other compounds, such as prostigmine, eserine, or related substances that have a carbamyl ester linkage or urethane structure, combine with both the anionic and the esteratic sites. After choline is split off, a carbamylated enzyme is left that is hydrolyzed very slowly. This type of inhibition is slowly reversible. Substances such as diisopropylphosphofluoridate form stable diisopropylphosphate esters with the serine residue of the esteratic site, resulting in irreversibly inhibited acetylcholinesterase. This type of inhibition characterizes insecticides and nerve gases. Compounds with a strongly cationic group at an appropriate intramolecular distance from a nucleophilic group, such as 2-pyridine aldoxime methiodide, rapidly remove the diisopropylphosphate group from the esteratic site, restoring enzyme activity. 2-Pyridine aldoxime methiodide has been used successfully as an antidote for diisopropylphosphofluoridate poisoning. Comprehensive reviews on acetylcholinesterase inhibitors and their modes of action have been published [27, 32].

\section{The Erythrocyte and Its Membrane}

The mature erythrocyte is a nonnucleated, biconcave, disc-shaped cell containing a high concentration of hemoglobin [9]. This unique cell is programmed in such a way that in its life span of 120 days and $280 \mathrm{~km}$ of continuous travel it is an effective vehicle for the supply of oxygen to all body tissues. Although it appears that the cell does not expend energy in fulfilling its known primary functions of transporting oxygen and carbon dioxide, the maintenance of the erythrocyte in a functional state involves energy expenditure. Essential to the rapid oxygenation of hemoglobin in the lungs and to the comparably rapid deoxygenation in the tissues is a structurally intact erythrocyte, i.e., the hemoglobin must be enclosed within the relatively impermeable envelope or membrane. Conditions that affect the functional and structural integrity of this membrane may lead to an ineffective and short lived cell.

As indicated above, the erythrocyte membrane has been extensively studied in relation to composition, immunologic and rheologic properties, permeability, active transport, and molecular organization. However, the possibility that membrane abnormalities of an enzymatic nature $[31,112]$ may be associated with several inherited or acquired hemolytic disorders has not received much attention. The erythrocyte membrane, composed primarily of lipid and protein, like the membranous structures of other cells, possesses specific enzymes [90]. An enzyme is considered to be located on the membrane if it cannot be removed by manipulations that render the membrane hemoglobin free. Hence, only the enzymes indicated in Table II are considered to form an integral part of the erythrocyte membrane.

\section{Acetylcholinesterase in the Erythrocyte}

The capacity of erythrocytes to split acetylcholine was first described by Galehr and Plattner [33] in

Table Ir. Enzymes of the erythrocyte membrane

\begin{tabular}{ll}
\hline \multicolumn{1}{c}{ Enzymes } & \multicolumn{1}{c}{ References } \\
\hline Acid proteases and peptidases & {$[40,92]$} \\
Diphosphopyridinenucleotidase & {$[35]$} \\
Triphosphopyridinenucleotidase & {$[35]$} \\
Phosphatases of various specificities & {$[20,34,41,52,91,103]$} \\
Cation-dependent adenosinetri- & {$[41,75]$} \\
$\quad$ phosphatases & \\
5'-Adenosinemonophosphate deam- & {$[79]$} \\
inase & {$[17,41]$} \\
Adenylate kinase & {$[52]$} \\
Diglyceride kinase & {$[72]$} \\
Phosphoglycerate kinase & {$[63]$} \\
Sialyltransferases & {$[16,25,82,90,105]$} \\
Glycolytic enzymes & {$[11]$} \\
Acetylcholinesterase &
\end{tabular}


1927. Alles and Hawes [1] demonstrated in 1940 that the erythrocyte enzyme resembled the brain esterase but differed markedly from the cholinesterase found in serum. Sabine [86] observed large increases in exythrocyte acetylcholinesterase activity in dogs after phlebotomy and in man after blood loss. In pernicious anemia a reproducible sequence of events was established: in relapse, the enzyme activity was relatively low, but it rose sharply above normal with the reticulocyte response and then declined progressively as remission was established. Similar patterns were found in other anemias. From these observations it was inferred that erythrocyte acetylcholinesterase activity above normal is a reflection of accelerated erythropoiesis.

The first direct evidence that increased acetylcholinesterase activity is a characteristic of young erythrocyte was obtained by Pritchard [78] in 1949. He separated by centrifugation the erythrocytes of rats subjected to blood loss into reticulocyte-rich and reticulocyte-poor populations. High activity was found in the reticulocyte-rich and low activity in the reticulocytepoor fractions. Sabine [87, 88] obtained similar results by applying the same procedure to blood from patients with various hematologic disorders. By transfusing erythrocytes of group $O$ into A-type normal recipients, and then isolating the donor's cells, Allison and Burn [2] demonstrated that the loss in acetylcholinesterase activity with time was compatible with an exponential decay curve with the assumption that in normal subjects cells of all ages are present in equal quantities. Subsequent studies have confirmed the notion that the activity of exythrocyte acetylcholinesterase is related to cell age $[3,45]$. However, an exception is seen in pa-

Table III. Erythrocyte acetylcholinesterase activity of some animal species

\begin{tabular}{lcc}
\hline \multirow{2}{*}{ Species } & \multicolumn{2}{c}{ Relative acetylcholinesterase activity } \\
\cline { 2 - 3 } & Zajicek [118] & $\begin{array}{c}\text { Callahan and } \\
\text { Kruckenberg [15] }\end{array}$ \\
\hline Man & 1.00 & 1.00 \\
Chimpanzee & & 0.71 \\
Monkey & 0.88 & 0.64 \\
Cow & & \\
Pig & 0.32 & 0.16 \\
Guinea pig & & 0.14 \\
Goat & 0.30 & 0.12 \\
Horse & & 0.12 \\
Dog & 0.21 & 0.08 \\
Rabbit & 0.12 & 0.05 \\
Rat & 0.01 & 0.02 \\
Cat & & \\
\hline
\end{tabular}

tients with paroxysmal nocturnal hemoglobinuria (see below).

Brauer and Root [11] in 1945 showed that after in vitro hemolysis, acetylcholinesterase activity can be recovered in the erythrocyte membrane. Studies with proteolytic enzymes, which are unable to traverse the erythrocyte membrane, have indicated that acetylcholinesterase or its active sites are located at or near the outer surface of the human erythrocyte $[7,30,51$, 74]. It has been suggested on the basis of a molecular weight of 90,000 or $180,000 /$ active site that $0.2 \%$ of human erythrocyte membrane proteins is active acetylcholinesterase [6]. The enzyme of human erythrocytes has been separated by ion exchange chromatography into two components [95, 96] and studies by Coates and Simpson [19] have shown genetic variations of these components. The membrane location of acetylcholinesterase prompted earlier investigators [53] to link the activity of this enzyme with the active transport of potassium, inasmuch as erythrocyte $\mathrm{K}+$ was lost in the presence of acetylcholinesterase inhibitors. However, this hypothesis has been disputed on the grounds that synthesis of acetylcholine by erythrocytes could not be demonstrated to be sufficiently active for the continuous operation of a $\mathrm{K}^{+}$transport system [67]. Furthermore, the concentrations of inhibitor required to prevent $\mathrm{K}+$ transport were up to 1,000 times higher than those needed to inhibit acetylcholinesterase activity [106]. The studies of Skou [99] and Post et al. [75] have established that the active transport of monovalent cations in and out of the erythrocyte is linked to a sodium-potassium-magnesium-dependent adenosine triphosphatase, present in the membrane.

Of the mammals studied, man has the highest acetylcholinesterase activity in the erythrocytes, whereas the cat has the lowest. Zajicek [118] has demonstrated an inverse distribution of acetylcholinesterase activity between erythrocytes and platelets in man and the cat, showing that in the former the enzyme activity is highest in the erythrocytes and almost absent in platelets, whereas in the latter the activity is very low in erythrocytes and extremely high in platelets. In Table III the activity of acetylcholinesterase of erythrocytes of different animals is compared with that of normal adult humans.

\section{Measurement of Erythrocyte Acetylcholinesterase}

The methods used for the estimation of acetylcholinesterase activity are based on the measurement of the rate of hydrolysis of acetylcholine or of an 
appropriate analogue such as acetylthiocholine [54, 115]. One simple method is the colorimetric technique of Ellman et al. [26] which uses acetylthiocholine as substrate in the presence of dithionitrobenzoate and quinidine sulfate (to inhibit pseudocholinesterase) in $0.1 \mathrm{M}$ sodium-potassium phosphate buffer $(\mathrm{pH} 8.0)$ and at $25^{\circ}$. The thiocholine liberated reacts with dithionitrobenzoate, yielding a yellow color that is measured spectrophotometrically at $412 \mathrm{~nm}$. Table IV shows the enzyme activity in erythrocytes of normal adults, newborn infants, and patients with disorders characterized by a reduction of acetylcholinesterase activity as obtained in our laboratory. Specific activity is expressed as change in absorbance per minute per milligram of hemoglobin.

\section{Erythrocyte Acetylcholinesterase Activity in Neonates}

The erythrocyte of the neonate differs in many respects from that of the adult individual $[8,13,55$, $69,121]$. The circulating blood at birth contains two kinds of hemoglobin, a fetal type, which comprises 0.80 of the whole, and the adult type, which makes up the remaining 0.20. Receptors of the $\mathrm{ABO}$, Lewis, and Ii blood group systems are not fully developed at birth, and the cells have a greater susceptibility to substances that generate methemoglobin. Electron microscopy has shown that vacuoles beneath the cell membrane, not present in erythrocytes from adults, are fairly common in cells from neonates. The membranes of cells from adults have more lecithin and less sphingomyelin than those from newborn infants, although both types of erythrocytes have the same total phospholipid content.

Despite the fact that the blood from normal neonates has a higher proportion of younger cells than that of adult individuals [70], acetylcholinesterase activity of the newborn's circulating erythrocytes is considerably less than that of the adult's [58]. Burman [14] has shown that mean acetylcholinesterase activity of cord erythrocytes was $53 \%$ of that of adult erythrocytes and that adult levels were reached by $3-5$ months of age. By separating the erythrocytes into light and heavy fractions (youngest and oldest cells, respectively), he also demonstrated that acetylcholinesterase activity was higher in the fraction containing most of the young cells. No changes in acetylcholinesterase activity were found by Burman in nine patients with $\mathrm{Rh}$ hemolytic disease and in two patients with $\mathrm{ABO}$ hemolytic disease of the neonate [14]. Volpato et al. [110] demonstrated low acetylcholinesterase activity at birth and
Table IV. Erythrocyte acetylcholinesterase activity in man ${ }^{1}$

\begin{tabular}{lc}
\hline \multicolumn{1}{c}{ Study subjects } & Specific activity \\
\hline $\begin{array}{l}\text { Normal adult (60) } \\
\text { Paroxysmal nocturnal hemoglobinuria }\end{array}$ & $153 \pm 24$ \\
$\quad$ (5) & $60,45,29,22$ \\
Autoimmune hemolytic anemia (2) & 43,46 \\
Normal full term neonates (253) & $95 \pm 15$ \\
Full term neonates with hemolytic dis- & \\
$\quad$ ease & $98 \pm 16$ \\
$\quad$ Rh disease (65) & $57 \pm 15$ \\
ABO disease (90) & $88 \pm 15$ \\
Infants of low birthweight appropriate & \\
$\quad$ for gestational age (120)
\end{tabular}

${ }^{1}$ Numbers in parenthesis indicate number of subjects tested.

${ }^{2}$ Mean $\pm \mathrm{SD}$.

showed a gradual increase to adult values by the 3rd week of life. They found similar enzyme activity in the erythrocytes of full term and of premature infants. However, reduced acetylcholinesterase activity was noted in 7 out of 26 infants with hyperbilirubinemia. Kaplan and Tildon [62] confirmed the results of earlier investigators by demonstrating that the enzyme activity at birth was $63 \%$ of adult values. In contrast to the findings of Volpato et al. [110], these authors demonstrated a further reduction in activity by 3-9 wreeks of life, which is compatible with the evidence that reduced erythropoiesis after birth results in an older erythrocyte population [61]. As expected, values approaching adult levels were found in infants of 10-17 weeks of age [62]. Although the concentration of reticulocytes was not determined in this investigation, the activity of glucose 6-phosphate dehydrogenase, an enzyme located intracellularly, was used as an additional variable. The activity of this enzyme, which is higher in the neonate than in the adult [101], was lower in the group of infants of 3-9 weeks of age than at birth and slightly higher by 10-17 weeks of age [62]. Zefirov and Kovalev [120] reported that acetylcholinesterase activity in full term infants did not change during the 1st week of life. Studies with erythrocytes from infants of low birthweight have shown that acetylcholinesterase activity is slightly lower than that of full term babies [50]. When the infants of low birthweight were followed for up to 6 weeks, there was an initial slight decline in activity associated with a small increase in glucose 6-phosphate dehydrogenase activity.

\section{Erythrocyte Acetylcholinesterase Deficiency in $A B O$ Hemolytic Disease of the Neonate}

During an investigation to establish correlation between erythrocyte survival and erythrocyte enzyme 
activity in the first days of life, Kaplan et al. [60] found a consistent reduction in acetylcholinesterase activity in newborn infants affected with $\mathrm{ABO}$ hemolytic disease. No decrease in enzyme activity was noted in infants with $\mathrm{Rh}$ hemolytic disease, in infants with congenital spherocytosis, or in infants with unexplained neonatal hyperbilirubinemia. In infants with $\mathrm{ABO}$ disease, the activities of glucose 6-phosphate dehydrogenase and of inorganic pyrophosphatase [44] were higher than in normal neonates, reflecting the presence of more young erythrocytes in the peripheral blood. The characteristic reduction of acetylcholinesterase activity in $\mathrm{ABO}$ disease is transient, since by the 4th month of life normal adult levels are found $[60]$.

The finding of subnormal acetylcholinesterase activity in $\mathrm{ABO}$ disease has now been confirmed by several investigators [24, 36, 71, 89, 98], and Stocker et al. [102] suggest its use as a clinical aid in evaluating infants for exchange transfusion in $\mathrm{ABO}$ hemolytic disease. Others have not found any association between the levels of acetylcholinesterase activity and severity of clinical disease $[36,60]$.

Investigations to elucidate the nature and significance of reduced acetylcholinesterase activity in $\mathrm{ABO}$ hemolytic disease of the neonate, like the findings with the deficient cells of paroxysmal nocturnal hemoglobinuria [3], have failed to reveal differences between the enzyme from these sources and the acetylcholinesterase from normal individuals. No inhibitors of acetylcholinesterase could be found in patients with reduced enzyme activity [47] and no differences in regard to substrate specificity, $\mathrm{pH}$ profile, $K_{m}$, effects of inhibitors $[47,71]$ and of inactivators $[42,43,46]$, and thermostability were found when enzyme from acetylcholinesterase-deficient erythrocytes was compared with that of normal cells. The report by Ferrone et al. [29] that the reduced acetylcholinesterase activity of erythro-

Table $V$. Conditions with reduced erythrocyte acetylcholinesterase activity

\section{Consistent finding}

Paroxysmal nocturnal hemoglobinuria

$\mathrm{ABO}$ hemolytic disease of the neonate

"Familial" reduction in acetylcholinesterase activity

Severe poisoning with acetylcholinesterase inhibitors

Occasional finding

Autoimmune hemolytic anemia

Erythroleukemia

Acute leukemia cytes from newborn infants with $\mathrm{ABO}$ disease was more resistant to heat denaturation than the enzyme activity of the cells from normal infants could not be confirmed in our laboratory.

\section{Acetylcholinesterase Activity in Infants of ABO-incom- patible Pregnancies}

Since $\mathrm{ABO}$ hemolytic disease of the neonate does not represent a clearly defined clinical entity, but a loose complex of clinical, hematologic, and immunologic abnormalities [60, 80], a continuous spectrum of levels of acetylcholinesterase activity in offsprings from $\mathrm{ABO}$ incompatible matings is to be expected. The comparison between full term infants of $\mathrm{ABO}$-compatible pregnancy and infants of $\mathrm{ABO}$-incompatible pregnancy but without signs of hemolytic disease reveals that acetylcholinesterase activity is somewhat lower in the latter group of children ( $98 \pm 16$ versus $91 \pm 12)$. This difference is amplified when fractions comprising the oldest cells are examined and in 20\% of babies of $\mathrm{ABO}$-incompatible pregnancy, acetylcholinesterase activity is significantly lower than in the other infants [48]. This finding is reminiscent of other anomalies described in normal-appearing neonates of $\mathrm{ABO}$-incompatible pregnancy $[80,83,122]$.

\section{Erythrocyte Acetylcholinesterase Deficiency in Other Disorders}

By the end of approximately 3 months of life, erythrocytes have adult levels of acetylcholinesterase activity [62]. Although the range of normal levels of erythrocyte acetylcholinesterase activity in the adult is relatively wide [5], increases in activity have been described in several conditions [86, 94]. However, it is not possible to ascribe great significance to these findings, since they occur during reticulocytosis and reticulocytes are known to have higher enzyme activity than erythrocytes [78].

Reduced acetylcholinesterase activity has been reported in a number of conditions (see Table V), but is consistently diminished only in patients with paroxysmal nocturnal hemoglobinuria [3, 22, 23, 68]. Since this disorder does not appear to be genetically determined, subnormal acetylcholinesterase activity would indicate an acquired membrane protein defect. Because acetylcholinesterase activity also seems to be reduced in bone marrow aspirates it has been suggested that the reduction is the result of defective cell membrane synthesis [3]. In both paroxysmal nocturnal 
hemoglobinuria [107] and $\mathrm{ABO}$ disease of the neonate [60], the activities of other membrane enzymes do not seem to be affected. One family in which several members had reduced acetylcholinesterase activity without apparent disease has been described by Johns [57]. In severe poisoning with acetylcholinesterase inhibitors (see above) the levels of enzyme activity are usually diminished, with return to normal after the elimination of the affected cells [37].

Moderate reduction in activity has also been reported in some individuals with autoimmune hemolytic anemia $[10,18,49,93,97,104,108]$. Sirchia et al. [97] found an association between diminished enzyme activity and the types of globulins coating the erythrocytes. Acetylcholinesterase activity appeared subnormal only in those cases where a $\gamma$-globulin antibody coated the erythrocytes, irrespective of the presence of complement. The reduced enzyme activity in some patients with autoimmune hemolytic anemia seems to reflect an abnormal decline in activity with erythrocyte aging [93] as well as a relative acetylcholinesterase deficiency of the youngest circulating cells [49]. Diminished activity has also been reported in cases of erythroleukemia [56] and acute leukemia [119], but the significance of these findings is not understood.

\section{Possible Mechanisms for Erythrocyte Acetylcholin- esterase Deficiency}

Inasmuch as the reduction of acetylcholinesterase activity in paroxysmal nocturnal hemoglobinuria seems to be an intrinsic cellular defect, the possibility of deficient enzyme synthesis has been considered [3]. In $\mathrm{ABO}$ disease of the neonate, and, in some cases, of autoimmune hemolytic anemia, the presence of antibodies may interfere with the correct translation of the genetic message specific for the synthesis of the enzyme protein, thereby resulting in either reduced enzyme synthesis or in a case in which the synthesis proceeds correctly, but the presence of antibodies interferes with the correct incorporation of acetylcholinesterase into the erythrocyte membrane. On the other hand, the possibility that reduced acetylcholinesterase activity represents the expression of a direct effect of certain serum components on the erythrocyte membrane has been tested repeatedly [60, 93, 104]. However, no evidence could be found to support this contention, because when normal erythrocytes are treated with immune isoantibodies, serum from patients with paroxysmal nocturnal hemoglobinuria or autoimmune hemolytic disease, under a variety of experimental conditions, no effect on acetylcholinesterase is noted.

\section{Acetylcholinesterase Activity and Erythrocyte Aging}

One of the most characteristic examples of metabolic modifications occurring during development takes place during erythrocyte maturation $[12,76]$. The erythroid cell up to the erythroblast state is endowed with a full complement of metabolic activities. Thus, the marrow cell synthesizes DNA, RNA, proteins, heme, and lipids, it metabolizes sugars aerobically and anaerobically, oxidizes through the tricarboxylic acid cycle, and phosphorylates oxidatively through the cytochrome system. At the adult normoblast stage and at the reticulocyte stage, many of these functions start to disappear and the metabolism of the circulating erythrocytes depends mainly on the utilization of monosaccharides. During the lifespan of 120 days the aging process of the erythrocytes is characterized by specific modifications. The cells have a tendency toward sphericity; the granular membrane becomes smooth, and there is a decrease in electric charge. Furthermore, there is an increase in methemoglobin and in specific gravity, as well as a decrease in osmotic resistance, water, potassium content, and overall cellular metabolism.

By using techniques based on the age-dependent increase in specific gravity it is possible to separate erythrocytes in accordance with their age [77]; cell fractions thus obtained can be employed for enzyme assays. Acetylcholinesterase activity, like the activity of many intracellularly located enzymes [12], gradually declines as the erythrocyte ages [47]. The relationship between the decline in activity and structural and functional alterations which determine the ultimate removal of the aged erythrocyte from the circulation have not been elucidated. It remains unclear whether the changes in activity are related to an actual loss of enzyme protein or a progressive enzyme denaturation, or are a reflection of a modified enzyme with decreased catalytic efficiency.

When erythrocytes from a normal adult individual are separated into populations of increasing age, a gradual decline in acetylcholinesterase activity can be observed [49]. By comparison, a much more accelerated decrease in activity is seen in patients with reduced enzyme activity, either because of $\mathrm{ABO}$ hemolytic disease or because of autoimmune hemolytic anemia [49]. An exception to the rule that acetylcholinesterase 
activity declines as the circulating erythrocytes age, is seen in paroxysmal nocturnal hemoglobinuria [3, 47]. In this condition, the activity is higher in the circulating older cells than in reticulocytes. This has been explained as being the result of a dual population of cells: one short lived and another with normal survival [59], one complement sensitive and another, complement insensitive [64, 84].

\section{Dissociation between Acetylcholinesterase Activity and Reticulocyte Concentration}

Although acetylcholinesterase activity is increased in younger cells and decreased in older cells, the overall enzyme activity is higher in adults than in neonates $[14,62]$, despite the greater reticulocyte content in the blood of the latter [70]. The dissociation between acetylcholinesterase activity and reticulocyte content in newborn infants becomes even more significant when viewed in the context of the activity of other erythrocyte enzymes. For example, the activities of the intracellularly located glucose 6-phosphate dehydrogenase [47] and inorganic pyrophosphatase [44] are increased not only in fractions containing the youngest cells but also in unseparated erythrocyte specimens from normal infants and from neonates with $\mathrm{ABO}$ disease [60]. These observations would exclude the possibility that the reduced acetylcholinesterase activity observed in $\mathrm{ABO}$ disease is the result of a preferential elimination from the circulation of younger cells which possess stronger $\mathrm{A}$ and $\mathrm{B}$ antigens, thereby leaving a cell population of older mean age [38].

It has been suggested that since fetal erythropoiesis is greatly accelerated toward the end of intrauterine life, a premature delivery of cells into the circulation could take place [121]. This could result in the formation of cells similar to the "stress reticulocyte" produced in the adult in response to hemorrhage or hemolysis [39, 81]. During "stress reticulocytosis" the normoblasts skip a generation and lose their nucleus at the polychromatophilic stage to become reticulocytes without going through the stage of orthochromatic normoblasts. This possibly incomplete maturation could be correlated not only with the dissociation of acetylcholinesterase activity and reticulocyte concentration in erythroblastotic infants, but also with the dissociation noted in all neonates, because only by 3 months of life does acetylcholinesterase activity reach adult levels [62].

Thus far, only quantitative differences in acetylcholinesterase activity have been noted. These do not distinguish between cells having fewer enzyme molecules and molecules arranged in a different spatial configuration, less favorable for interaction with substrate. The relatively low erythrocyte acetylcholinesterase activity and somewhat reduced adenosine triphosphatase activity [114] in neonates are in striking contrast to the activities of most intracellularly located enzymes which are higher in neonates than in adults $[60,101]$. If the "stress reticulocyte" hypothesis is correct this could mean that the complement of intracellular enzymes is synthesized at an earlier temporal stage than acetylcholinesterase (and perhaps other membrane components as well). Also, the possibility that the lower erythrocyte acetylcholinesterase activity in neonates is the result of an accelerated enzyme inactivation as a function of cell age cannot be excluded.

\section{Summary}

This review summarizes the present knowledge with respect to human erythrocyte acetylcholinesterase. Although the physiologic functions of this enzyme in the erythrocyte remain obscure, its physicochemical and biochemical properties, as well as its position within the erythrocyte membrane, are better understood. Because of its location at or near the outer cell surface, the study of acetylcholinesterase might have relevance for basic disease processes at the cellular level. Of the enzymes recognized in the membrane of the human erythrocyte, alterations in activity associated with pathologic conditions are found regularly only with acetylcholinesterase. This review provides a summary of the knowledge concerning changes in the activity of this enzyme as related to health and disease, age of the individual, and erythrocyte aging.

\section{References and Notes}

1. Alles, G. A., and Hawes, R. C.: Cholinesterases in the blood of man. J. Biol. Chem., 133: 375 (1940).

2. Alurson, A. C., ANd Burn, G. P.: Enzyme activity as a function of age in the human erythrocyte. Brit. J. Haematol., 1: 291 (1955).

3. Audrtore, J. V., and Hartmann, R. C.: Paroxysmal nocturnal hemoglobinuria. II. Exythrocyte acetylcholinesterase defect. Amer. J. Med., 27: 401 (1959).

4. Augustinsson, K.-B.: Cholinesterases: A study in comparative enzymology. Acta Physiol. Scand., 15 (Suppl. 52): 1 (1948).

5. Augustinsson, K.-B.: The normal variation of human blood cholinesterase activity. Acta Physiol. Scand., 35: 40 (1955).

6. Bellhorn, M. B., Blumenfeld, O. O., and Gallop, P. M.: Acetylcholinesterase of the human erythrocyte. Biochem. Biophys. Res. Commun., 39: 267 (1970). 
7. Bender, W. W., Garan, H., and Berg, H. C.: Proteins of the human exythrocyte membrane as modified by pronase. J. Mol. Biol., 58 : 783 (1971).

8. Betke, K., Kleihauer, E., Gärtner, C., ANd Schiebe, G.: Verminderung von Methämoglobinreduktion, Diaphoraseaktivität und Flavinen in Erythrozyten jungcr Säuglinge. Arch. Kinderheilk., 170: 66 (1964).

9. BrRd, G. W. G.: The red cell. Brit. Med. J., 1: 293 (1972).

10. Brabec, V., Brconová, J., Friedmann, B., Kout, M., Mircevová, L., Palek, J., Vopatová, M., and Volek, V.: Stoffwechselveränderungen in Erythrozyten bei der autoimmunen hämolytischen Krankheit. Acta Haematol., $34: 88$ (1965).

11. Brauer, R. W., AND Root, M. A.: The cholinesterase of human erythrocytes. Fed. Proc, 4: 113 (1945).

12. Brok, F., Ramot, B., Zwang, E., and Danon, D.: Enzyme activities in human red blood cells of different age groups. Israel J. Med. Sci., 2: 291 (1966).

13. Brown, A. K.: Erythrocyte metabolism and hemolysis in the newborn. Pediat. Clin. N. Amer., 13: 879, (1966).

14. Burman, D.: Red cell cholinesterase in infancy and childhood. Arch. Dis. Childhood, 36: 362, (1961).

15. Callahan, J. F., and Kruckenberg, S. M.: Erythrocyte cholinesterase activity of domestic and laboratory animals: Normal levels for nine species. Amer. J. Vet. Res., 28: 1509 (1967).

16. Carraway, K. L., and Shin, B. C.: Specific modification, isolation, and partial characterization of an erythrocyte membrane protein. J. Biol. Chem., 247: 2102 (1972).

17. Cerlettr, P., AND DE Rrtrs, G.: Enzymes of the red blood cell membrane: Adenylate kinase activity. Clin. Chim. Acta, 7: 402 (1962).

18. Choremis, C., Nicolopoulos, D., Metaxotou, K., AND Moschos, A. L.: Erythrocyte cholinesterase activity in hemolytic anemias. Acta Paediat. Scand., 54: 218 (1965).

19. Contes, P. M., And Srmpson, N. E.: Genetic variations in human erythrocyte acetylcholinesterase. Science, 175: 1466 (1972).

20. Comperts, B. D.: Directional properties of 2,3-diphospho-Dglycerate-2-phosphohydrolase in the human red-cell membrane. Biochem. J., 100: 44P (1966).

21. COOPER, R. A.: Lipids of human red cell membrane: Normal composition and variability in disease. Seminars Hematol. 7: $296(1970)$

22. De SANDRe, G., AND Ghrotto, G.: An enzymic disorder in the erythrocytes of paroxysmal nocturnal haemoglobinuria: A deficiency in acetylcholinesterase activity. Brit. J. Haematol., 6: 39 (1960).

23. De Sandre, G., Ghiotto, G., and Mastella, G.: L'acetilcolinesterasi eritrocitaria. II. Rapporti con le malattia emolitica. Acta Med. Patavina, 16: 310 (1956).

24. Di Toro, R., Ansanelly, V., and Granata, E.: Il dosaggio dell'acetelcolinesterasi exitrocitaria nella diagnosi di malattia emolitica del neonato da isoimmunizzazione ABO. Pediatria, 74: 813 (1966).

25. Duchon, G., ANd Colluer, H. B.: Enzyme activities of human erythrocyte ghosts: Effects of various treatments. J. Membrane Biol., 6: 138 (1971).

26. Ellman, G. L., Courtney, K. D., Andres, V., JR., and Featherstone, R. M.: A new and rapid colorimetric deter- mination of acetylcholinesterase activity. Biochem. Pharmacol., 7: 88 (1961).

27. Engel.hard, N., Prchal, K., and Nenner, M.: AcetylcholinEsterase. Angew. Chem., 79: 604 (1967).

28. Engelhart, E., ANd Loewi, O.: Fermentative Azetylcholinspaltung im Blut und ihre Hemmung durch Physostigmin. Arch. Exp. Path. Pharmakol., 150: 1 (1930).

29. Ferrone, S., Zanella, A., and Sirchia, G.: Red cell acetylcholinesterase in $\mathrm{ABO}$ hemolytic disease of the newborn. Experientia, 24: 495 (1968).

30. Firkin, B. D., Beal, R. W., and Mitchell, G.: The effects of trypsin and chymotrypsin on the acetylcholinesterase content of human erythrocytes. Australasian Ann. Med., 12: 26 (1963).

31. Firkin, B. G., ANd Wiley, J. S.: The red cell membrane and its disorders. Progr. Hematol., 5: 26 (1966).

32. Fukuro, T. R.: Relationships between the structure of organophosphorus compounds and their activity as acetylcholinesterase inhibitors. Bull. World Health Organ., 44: $31(1971)$.

33. Galehr, O., and Plattner, F.: Über das Schicksal des Acetylcholins im Blute. Seine Zerstörung im Blute verschiedener Säugetiere. Pflueger's Arch. Gesamte Physiol. Menschen Tiere, 218: 506 (1927).

34. Garrahan, P. J., Pouchan, M. I., and Rega, A. F.: Potassium activated phosphatase from human red blood cells. The mechanism of potassium activation. J. Physiol., 202: 305 (1969).

35. GASIOROWSKA, I., AND RACZYNSKA-BoJANowSKA, K.: NAD and NADP glycohydrolase of human erythrocytes. Bull. Acad. Pol. Sci. Ser. Sci. Biol., 11: 417 (1963).

36. Gerlini, G., Otxaviano, S., Sbraccia, C., Carapella, E., and BONANNI, V.: Comportamento dell'attività acetilcolinesterasica eritrocitaria nella malattia emolitica del neonato da incompatibilità $\mathrm{ABO}$ in rapparto all'eta delle emazie. Riv. Clin. Pediat., 81: 742 (1968).

37. Golddn, A. R., Rubenstein, A. H., Bradlow, B. A., AND ELLIoT, G. A.: Malathion poisoning with special reference to the effect of cholinesterase inhibition on erythrocyte survival. New Engl. J. Med., 271: 1289 (1964).

38. GRUNDBACHER, F. J.: ABO hemolytic disease of the newborn: A family study with emphasis on the strength of A antigen. Pediatrics, 35: 916 (1965).

39. Hanna, I. R. A., Tarbutt, R. G., and Lamerton, L. F.: Shortening of the cell-cycle time of erythroid precursors in response to anaemia. Brit. J. Haematol., 16: 381 (1969).

40. Haschen, R. J., Farr, W., and Grof, F.: Das proteolytische System der Exythrozyten. Folia Haematol. (Leipzig), 83: 127 (1965).

41. Heller, M., and Hanahan, D. J.: Erythrocyte membranebound enzymes. ATPase, phosphatase and adenylate kinase in human, bovine and porcine erythrocytes. Biochim. Biophys. Acta, 255: 239 (1972).

42. HERZ, F.: Inactivation of erythrocyte acetylcholinesterase by penicillin. Nature, 214: 497, (1967).

43. HERz, F.: On the effects of tannic acid on exythrocyte membrane acetylcholinesterase. Proc. Soc. Exp. Biol. Med., 127: 1240 (1968).

44. Herz, F., Herold, F. S., and Kaplan, E.: Erythrocyte inor- 
ganic pyrophosphatase activity in the newborn infant. Proc. Soc. Exp. Biol. Med., 121: 536 (1966).

45. Herz, F., AND Kaplan, E.: A microtechnic for the separation of erythrocytes in accordance with their density. Amer. J. Clin. Pathol., 43: 181 (1965).

46. Herz, F., AND Kaplan, E.: Modifications of the erythrocyte membrane by glutaraldehyde: Effect on acetylcholinesterase. Proc. Soc. Exp. Biol. Med., 140: 720 (1972).

47. Herz, F., Kaplan, E., and Scheye, E. S.: Differences between the red cell acetylcholinesterase defects of paroxysmal nocturnal hemoglobinuria and of $\mathrm{ABO}$ hemolytic disease. Acta Haematol., 39: 85 (1968).

48. Herz, F., Kaplan, E., and Scheye, E. S.: Red cell acetylcholinesterase deficiency in $\mathrm{ABO}$ hemolytic disease of the newborn. Clin. Chim. Acta, 36: 537 (1972).

49. Herz, F., Kaplan, E., ANd Scheye, E. S.: Red cell acetylcholinesterase deficiency in autoimmune hemolytic anemia and in paroxysmal nocturnal hemoglobinuria. Clin. Chim. Acta, 38: 301 (1972).

50. Herz, F., KAPlan, E., AND SCHEYe, E. S.: Erythrocyte acetylcholinesterase and glucose-6-phosphate dehydrogenase in newborn infants of low birth weight (in preparation).

51. Herz, F., Kaplan, E., and Stevenson, J. H., JR.: Acetylcholinesterase inactivation of enzyme-treated erythrocytes. Nature, 200: 901 (1963).

52. Hokin, L. E., ANd Hokin, M. R.: Diglyceride kinase and phosphatidic acid phosphatase in erythrocyte membranes. Nature, 189: 836 (1961).

53. Holland, W. C., ANd Greig, M. E.: Studies on permeability. Effect of acetylcholine and physostigmine on permeability to potassium of $\mathrm{dog}$ erythrocytes. Arch. Biochem., 26: 151 (1950).

54. Holmstedt, B.: Distribution and determination of cholinesterases in mammals. Bull. World Health Organ., 44: 99 (1971).

55. Holroyde, C. P., Oski, F. A., and Gardner, F. H.: The "pocked" erythrocyte. Red-cell surface alterations in reticuloendothelial immaturity of the neonate. New Engl. J. Med., 281: 516 (1969).

56. Horton, B. F., Chernoff, A., and Meadows, R. W.: The hemoglobin profile and erythroleukemia. Cancer, 26: 904 (1970).

57. JoHNs, R. J.: Familial reduction in red-cell cholinesterase. New Engl. J. Med., 267: 1344 (1962).

58. Jones, P. E. H., and McCance, R. A.: Enzyme activities in the blood of infants and adults. Biochem. J., 45: 464 (1949).

59. Kan, S. Y., and Gardner, F. H.: Life span of reticulocytes in paroxysmal nocturnal hemoglobinuria. Blood, 25: 759 (1965).

60. Kaplan, E., Herz, F., and Hsu, K. S.: Erythrocyte acetylcholinesterase activity in $A B O$ hemolytic disease of the newborn. Pediatrics, 33: 205 (1964).

61. Kaplan, E., AND Hsu, K. S.: Determination of erythrocyte survival in newborn infants by means of $\mathrm{Cr}^{51}$-labelled erythrocytes. Pediatrics, 27: 354 (1961).

62. Kaplan, E., and Trldon, J. T.: Changes in red cell enzyme activity in relation to red cell survival in infancy. Pediatrics, 32: 371 (1963).

63. Kim, Y. S., Perdomo, J., Bella, A., Jr., and Nordberg, J.: Properties of a CMP- $N$-acetylneuraminic acid: Glycoprotein sialytransferase in human serum and erythrocyte membrane. Biochim. Biophys. Acta, 244: 505 (1971).

64. Kunstling, T. R., AND Rosse, W. F.: Erythrocyte acetylcholinesterase deficiency in paroxysmal nocturnal hemoglobinuria ( $\mathrm{PNH})$ : A comparison of the complement-sensitive and insensitive populations. Blood, 33: 607 (1969).

65. LaCelle, P. L.: Alteration of membrane deformability in hemolytic anemias. Seminars Hematol., 7: 355 (1970).

66. Loewr, O., and Navratil, E.: Über humorale Übertragbarkeit der Herznervenwirkung. Über das Schicksal des Vagusstoffs. Pflueger's Arch. Gesamte Physiol. Menschen Tiere, 214: 678 (1929).

67. Mathias, P. J., and Sheppard, C. W.: Upper limit for acetylcholine content and synthesis in human erythrocytes. Proc. Soc. Exp. Biol. Med., 86: 69 (1954).

68. Metz, J., Bradlow, B. A., Lewis, S. M., and Dacie, J. V.: The acetylcholinesterase activity of the erythrocytes in paroxysmal nocturnal haemoglobinuria in relation to the severity of the disease. Brit. J. Haematol., 6: 372 (1960).

69. Neerhout, R. C.: Erythrocyte lipids in the neonate. Pediat. Res., 2: 172 (1968).

70. Oski, F. A., AND NaIman, J. L.: Red cell metabolism in the premature infant. I. Adenosine triphosphate levels, adenosine triphosphate stability, and glucose consumption. Pediatrics, 36: 104 (1965).

71. ÖZANd, P., ARTvrnll, S., AND YarimaǦan, S.: Investigation of the kinetic characteristics of red blood cell acetylcholinesterase in $\mathrm{ABO}, \mathrm{Rh}$ hemolytic disease of the newborn and thalassemia major cases. Turk. J. Pediat., 12: 1 (1970).

72. Parker, J. C., and Hoffman, J. F.: The role of membrane phosphoglycerate kinase in the control of glycolytic rate by active cation transport in human red blood cells. J. Gen. Physiol., 50: 893 (1967).

73. Passow, H.: Passive ion permeability of the exythrocyte membrane. Progx. Biophys. Mol. Biol., 19: 423 (1969).

74. Perona, G., Cortesi, S., Ghiotto, G., and De Sandre, G.: Loss of acetylcholinesterase in human erythrocytes treated with trypsin, papain or bromelin: Its relationship with susceptibility to acid lysis in vitro. Brit. J. Haematol. 11: 171 (1965).

75. Post, R. L., Merritt, C. R., Kinsolving, C. R., ANd Albright, C. D.: Membrane adenosine triphosphatase as a participant in the active transport of sodium and potassium in the human erythrocyte. J. Biol. Chem., 235: 1796 (1960).

76. Prankerd, T. A. J.: The ageing of red cells. J. Physiol., 143: 325 (1958).

77. Prentice, T. C., And Bishop, C.: Separation of rabbit red cells by density methods and characteristics of separated layers. J. Cell. Comp. Physiol., 65: 113 (1965).

78. Pritchard, J. A.: Erythrocyte age and cholinesterase activity. Amer. J. Physiol., 158: 72 (1949).

79. RaO, S. N., HaRA, L., ANd Askari, A.: Alkali cation-activated AMP deaminase of erythrocytes: Some properties of the membrane-bound enzyme. Biochim. Biophys. Acta, 151, 651 (1968).

80. Robrnson, G. C., Dunn, H. G., And Wong, L. C.: Observations on $A B O$ incompatibility between mother and infant. Acta Pediat., 48 (Suppl. 120): 1 (1960).

81. Robinson, S. H., And Tsong, M.: Hemolysis of "stress" 
reticulocytes: A source of erythropoietic bilirubin formation. J. Clin. Invest., 49: 1025 (1970).

82. Ronquist, G.: Enzyme activities at the surface of intact human erythrocytes. Acta Physiol. Scand., 76: 312 (1969).

83. ROSENFELD, R. E.: AB hemolytic disease of the newborn. Analysis of 1,480 cord blood specimens, with special reference to the direct antiglobulin test and to the role of the group O mother. Blood, 10: 17 (1955).

84. Rosse, W. F.: The life-span of complement-sensitive and insensitive red cells in paroxysmal nocturnal hemoglobinuria. Blood, 37: 556 (1971).

85. Rosse, W. F., ANd Lauf, P. K.: Effects of immune reactions on the red cell membrane. Seminars Hematol., 7: 323 (1970).

86. SABINE, J. C.: Choline esterase of blood cells and plasma in blood dyscrasias, with special reference to pernicious anemia. J. Clin. Invest., 19: 833 (1940).

87. SABINE, J. C.: The cholinesterase of erythrocytes in anemias. Blood, 6: 151 (1951).

88. SAbine, J. C.: Erythrocyte cholinesterase titers in hematologic disease states. Amer. J. Med., 27: 81 (1959).

89. Sbraccia, C., Carapella De Luca, E., and Bonanni, V.: L'attività acetilcolinesterasica eritrocitaria nei neonati con malattia emolitica da incompatibilità ABO. Minerva Pediat., 17: 1527 (1965).

90. SCHRIER, S. L.: Organization of enzymes in human erythrocyte membranes. Amer. J. Physiol., 210: 139, (1966).

91. Schröter, W., and Neuvians, M.: Membrane-bound 2,3diphosphoglycerate phosphatase of human erythrocytes. J. Membrane Biol., 2: 31 (1970).

92. Schulxz, K.: Über die Veränderung der Stromaproteaseaktivität menschlicher Erythrozyten während der Behandlung der perniciosen Anämie. Folia Haematol. (Leipzig), 79: 455 (1962).

93. SCott, G. L., ANd Rasbridge, M. R.: Red cell acetylcholinesterase and adenosinetriphosphatase activity in patients with a positive antiglobulin test. Scand. J. Haematol., 8: 53 (1971).

94. Scudamore, H. H., Vorhaus, L. J., II, and Kark, R. M.: Observations on erythrocyte and plasma cholinesterase activity in dyscrasias of the blood. Blood, 6: 1260 (1951).

95. Shafai, T., and Cortner, J. A.: Human erythrocyte acetylcholinesterase. I. Resolution of activity into two components. Biochim. Biophys. Acta, 236: 612 (1971).

96. Shafai, T., AND Cortner, J. A.: Human erythrocyte acetylcholinesterase. II. Evidence for the modification of the enzyme by ion-exchange chromatography. Biochim. Biophys. Acta, 250: 117 (1971).

97. Sirchia, G., Ferrone, S., Mercuriali, F., and Zanella, A.: Red cell acetylcholinesterase activity in autoimmune haemolytic anaemias. Brit. J. Haematol., 19: 411 (1970).

98. Sirchia, G., Srroni, A., Ferrone, S., and Masera, G.: L'acetilcolinesterasi eritrocitaria nella mallatia emolitica del neonato. Boll. Soc. Ital. Emat., 13: 197 (1965).

99. Skou, J. C.: Enzymatic basis for active transport of $\mathrm{Na}^{+}$ and $\mathrm{K}^{+}$across cell membranes. Physiol. Rev., 45: 596 (1965).

100. Stedman, E., Stedman, E., and Easson, K. H.: Cholinesterase: Enzyme present in blood-serum of horse. Biochem. J., 26: 2056 (1932).

101. Stewart, A. G., And Birkbeck, J. A.: The activities of lactate dehydrogenase, transaminase, and glucose-6-phosphate dehydrogenase in the erythrocytes and plasma of newborn infants. J. Pediat., 61: 395 (1962).

102. Stocker, F., Taminelli, F., And de Muralt, G.: Die Erythrozyten-Azetylcholinesterase als gutes Kriterium für die Indikation zur Austauschtransfusion bei der ABO-Hämolyse der Neugeborenen. Helv. Paediat. Acta, 24: 448 (1969).

103. Sudo, T., Kikumo, M., and Kurihara, T.: 2', $3^{\prime}$-cyclic nucleotide 3'-phosphohydrolase in human erythrocyte membranes. Biochim. Biophys. Acta, 255: 640 (1972).

104. Tanaka, K. R., Valentine, W. N., and Schneider, A. S. Red cell cholinesterase in Coombs autoimmune hemolytic anemia (AHA). Clin. Res., 12: 110 (1964).

105. TANner, M. J. A., AND Gray, W. R.: The isolation and functional identification of a protein from the human erythrocyte "ghost." Biochem. J., 125: 1109 (1972).

106. TAYlor, I. M., Weller, J. M., and Hastings, A. B.: Effect of cholinesterase and choline acetylase inhibitors on potassium concentrating gradient and potassium exchange of human erythrocytes. Amer. J. Physiol., 168: 658 (1952).

107. Thompson, B. H., Hanna, K. L., van Eys, J., and HartMANN, R. C.: Erythrocyte diphosphopyridine nucleotidase (NADase) in paroxysmal nocturnal hemoglobinuria. Proc. Soc. Exp. Biol. Med., 138: 827 (1971).

108. Tsukada, T., And Miwa, S.: Studies on erythrocyte acetylcholinesterase. Acta Haematol. Jap., 32: 353 (1969).

109. Uhlenbruck, G.: Über Mucoide von Zelloberflächen. Chimia, 25: 10 (1971).

110. Volpato, S., Baggio, P., and Sacchetro, A.: A propos de quelques activités enzymatiques érythrocytaire de la période néo-natale, dans les conditions normales et pathologiques. Ann. Pediat. (Paris), 38: 627 (1962).

111. WALlACH, D. F. H.: The dispositions of proteins in the plasma membranes of animal cells: Analytic approaches using controlled peptidolysis and protein labels. Biochim. Biophys. Acta, 265: 61 (1972).

112. WEED, R. I., AND ReED, C. F.: Membrane alterations leading to red cell destruction. Amer. J. Med., 41:681 (1966).

113. Wernstein, R. S., AND McNutr, N. S.: Ultrastructure of red cell membrane. Seminars Hematol., 7: 259 (1970).

114. Whaun, J. M., ANo Oski, F. A.: Red cell stromal adenosine triphosphatase (ATPase) of newborn infants. Pediat. Res., 3: 105 (1969).

115. WIrTer, R. F.: Measurement of blood cholinesterase. A critical account of methods of estimating cholinesterase with reference to their usefulness and limitations under different conditions. Arch. Environ. Health, 6: 537 (1963).

116. ZAHLER, P.: Blood group antigens in relation to chemical and structural properties of the red cell membrane. Vox Sang., 15: 81 (1968).

117. ZAHLER, P.: The structure of the exythrocyte membrane. Experientia, 25: 449 (1969).

118. ZAJICEK, J.: Studies on the histogenesis of blood platelets and megakaryocytes. Histochemical and gasometric investigations of acetylcholinesterase activity in the erythrocyteerythropoietic and platelet-megakaryocytic systems of various mammals. Acta Physiol. Scand., 40 (Suppl. 138): 1 (1957).

119. Zefrov, I. N.: Changes in the cholinesterase activity in the 
whole blood of children with acute leukemia. Vop. Okhr. Materin. Det., 10: 53 (1965).

120. Zefroov, Y. N., AND Kovalev, Y. R.: Activity of exythrocyte cholinesterase in newborns. Vop. Okhr. Materin. Det., 13: 39 (1968).

121. Zipurskx, A.: The erythrocytes of the newborn infant. Seminars Hematol. 2: 167 (1965).

122. Zuelzer, W. W., AND KAPLAN, E.: ABO heterospecific pregnancy and hemolytic disease. A study of normal and pathological variants. III. Hematologic findings and erythrocyte survival in normal infants. Amer. J. Dis. Child., 88. 307 (1954).

123. This work was supported by Grants nos. HD01461 and 5SO1-RR05478-10 from the National Institutes of Health, Public Health Service, Bethesda, Md. 20014.

124. Requests for reprints should be addressed to: Fritz Herz, Ph.D., Sinai Hospital, Baltimore, Md. 21215 (USA).

125. Accepted for publication December 19, 1972. 